\title{
The effects of changing story number and structural footprint area on building performance in reinforced-concrete buildings
}

\author{
Ercan Işık ${ }^{\mathrm{a}}$ (D), Nursima Sayın ${ }^{\mathrm{b}}$ (D), Ali Emre Ulu ${ }^{\mathrm{a}, *}$ (iD) \\ aBitlis Eren University, Department of Civil Engineering, TR-13000, Bitlis Turkey \\ bBitlis Eren University, Graduate Education Institute, TR-13000, Bitlis Turkey
}

\section{ART I C LE INFO}

\section{Article history:}

Received 22 April 2020

Received in revised form 29 May 2020

Accepted 29 May 2020

\section{Keywords:}

Footprint area

Pushover analysis

Number of story

Reinforced-concrete

Eigen value

\section{A B S T R A C T}

\begin{abstract}
Structural footprint area and number of stories occupy an important place among the factors affecting the behavior of buildings under earthquake effects. In this study, footprint area and number of stories are considered as two different variables. A sample reinforced-concrete building with all values such as structural system elements, dimensions, materials, material models and loading status is selected same in all different structural models. The structural analyzes were made for a single direction since the structure was chosen symmetrically. In each building model, the axle clearance has been increased by one meter in both directions. As the second variable, four different story numbers were chosen as 5, 6, 7 and 8 . Eigenvalue and static pushover analyzes were performed for the each structural model. Target displacement for damage estimation, period, stiffness and base shear force values were obtained for all models, respectively. Both, Eurocode 8-Part 3 and Turkish Seismic Design Code-2018 were considered in the analysis. As the building footprint area and number of story increase, period, displacement and target displacement increase for both codes.
\end{abstract}

(c) 2020. Turkish Journal Park Academic. All rights reserved.

\section{Introduction}

There are many parameters that can adversely affect the behavior of structures under loads. Determining the behavior of the structures under loads is directly related to their structural characteristics. The number of total stories is the one of important factor that determines the degree of damage in reinforced-concrete (RC) buildings after devastating earthquakes. There is a direct relationship between the number of stories and earthquake damages (Şengezer, 1999; Sucuoğlu, 2007; Yakut, 2004; Işılk, 2016; Hadzima-Nyarko and Šipoš, 2017; Özdemir et al., 2016; Işık et al., 2018). A great number of design variables were affect to the construction costs and structural analysis besides number of stories. These variables can be specified as shape and complexity of buildings plan, height of stories and service requirements of the building (İlerisoy and Tuna, 2018; Saidu et al., 2015).

It is important to give the necessary dimensions to the structural characteristics. The structural and non-structural system elements and other structural features that require size were expressed in three dimensions. The structural footprint area of the building keeps out an important role in the concept of size (Ișlk and Karaşin, 2020). The dimension of footprint area was calculated by width and length of the building. These dimensions were obtained from the sum of the axle openings forming the structural system.

Within the scope of this study, both the number of stories and structural footprint area were selected as variable for a sample RC building. Four different number of story was chosen as 5, 6, 7 and 8 in this study. The second variable was selected as footprint area. The selections were made changing the axle openings in both directions. Each axle clearance was selected as $4 \mathrm{~m}, 5 \mathrm{~m}$ and $6 \mathrm{~m}$ in both $\mathrm{X}$ and $\mathrm{Y}$ direction. The structural footprint area of the sample RC building model was changed according to axle clearance. Eigen value and static pushover analysis were performed for all structural models that considered in this study. Target displacement for damage estimation, period, frequency,

\footnotetext{
* Corresponding author: Ali Emre Ulu E-mail address: aeulu@beu.edu.tr ORCID: 0000-0001-7499-3891 (Ali Emre ULU), 0000-0001-8057-065X (Ercan IŞIK), 0000-0002-4392-8410 (Nurşima SAYIN)
} 
stiffness and base shear force values were obtained for all models through these analysis, respectively.

In the study, firstly, information was given about the types of analysis used. In the next section, detailed information about the structural models used in the study is expressed. In the next section, detailed information about the structural models used in the study is expressed. The results were interpreted and suggestions were made.

Most of the structures in Turkey are constructed with RC system. This study focuses on the interaction of horizontal and vertical dimensions with each other especially in RC structures under earthquake effects. Earthquake damages in RC structures reveal the importance of these two parameters. In this respect, this study can contribute in terms of science and practice for RC buildings.

\section{Method}

Eigenvalue and static pushover analysis were used in this study for structural analysis. Eigen value analyzes were conducted primarily for the building models created for each variable used in this study. Mode shapes and natural frequency for any structure can be obtained by eigenvalue analysis. Material properties always remain constant during the calculation. Briefly, it can be evaluated as pure elastic structural analysis. Structure-related modal period, frequency, modal participation factors, effective modal masses and their percentile values can be reached by eigen value analysis (Antoniou and Pinho, 2003; Seismossoft, 2014; Kutanis et al., 2017; Nikoo et al., 2017).

Static pushover analysis was used another analysis that used in this study. Earthquake performance and damage conditions of buildings can be calculated with this analysis generally. Static pushover analysis is called as non-linear calculation method, which is made by increasing the horizontal loads gradually under fixed vertical loads in RC structures. The earthquake impact analysis and accurate results for behaviour of building can be performed with this analysis more realistically. Deformation behaviours of all elements of the building and the inelastic behaviour of the material can be examined with this method (Estêvão and Oliveria, 2015; Ademovic et al., 2013; Chopra and Goel, 2002; Işı lk and Kutanis, 2015; Işı and Özdemir, 2017). A typical static pushover curve is shown in Figure 1.

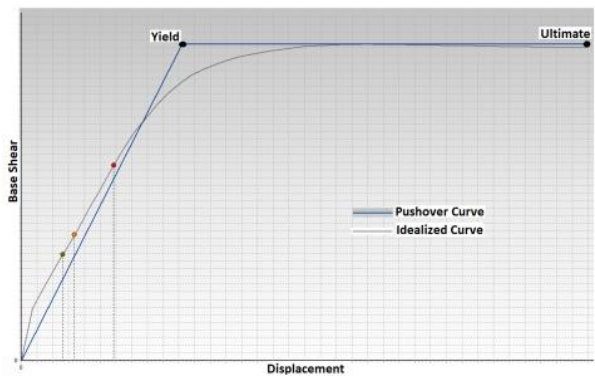

Figure 1. A typical static pushover curve

\subsection{Structural characteristics of building models}

Within the scope of the study, a sample RC building with different story numbers and structural footprint area was chosen. The structure was chosen symmetrically in both $\mathrm{X}$ and $Y$ directions. The blueprint of the sample building was shown in Figure 2.

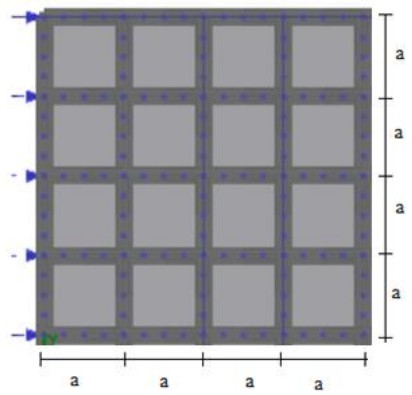

Figure 2. The blueprint of sample RC building

Analyzes were carried out under the Seismostruct software under an academic license (Seismosoft, 2016). The soil class was selected as ZE for all structural models. The building importance class was taken into account as the II. Class, thedampingratio as $5 \%$ and peak ground acceleration was selected $0.240 \mathrm{~g}$. Number of stories was kept constant and a value for footprint was selected as variable. For the value for a three different cases were considered. Considered structural dimensions are given in Table 1.

Table 1. Dimensions of the building models considered

\begin{tabular}{|c|c|c|c|}
\hline Model No & a (m) & a (m) & $\begin{array}{c}\text { Footprint Area } \\
\left(\mathrm{m}^{2}\right)\end{array}$ \\
\hline Model 1 & 4.0 & 4.0 & 256 \\
\hline Model 2 & 5.0 & 5.0 & 400 \\
\hline Model 3 & 6.0 & 6.0 & 576 \\
\hline
\end{tabular}

2D model of the buildings and loads applied to the models were shown in Figure 3.

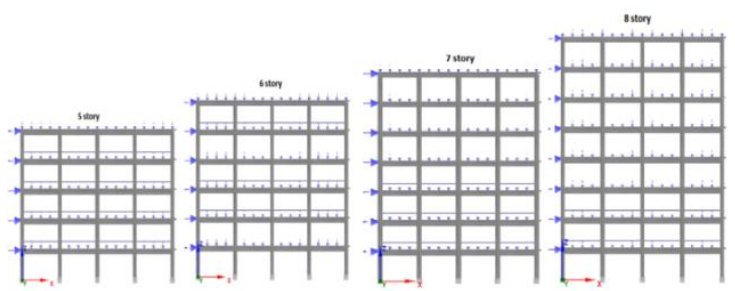

Figure 3. 2D building models for different number of stories

3D structural models that obtained from software were given in Figure 4.
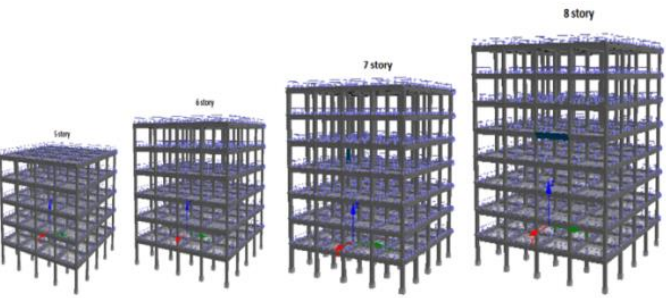

Figure 4. 3D building models for different number of stories 
C25-S420 was taken into consideration for RC structure. The transverse reinforcements were selected as $\phi 10 / 10$ in columns and $\phi 10 / 15$ in beams. The reinforcements used in all columns were selected as $4 \phi 20$ in corners, $4 \phi 16$ in topbottom sides and $4 \phi 16$ in left-right sides. The reinforcements used in all beams were selected as $4 \phi 16$ in lower, $5 \phi 18$ in upper, $2 \phi 12$ in sides, $4 \phi 10$ in lower-slab and $6 \phi 10$ in upper-slab. Column and beam cross sections used in the reinforced concrete building are given in Figure 5.

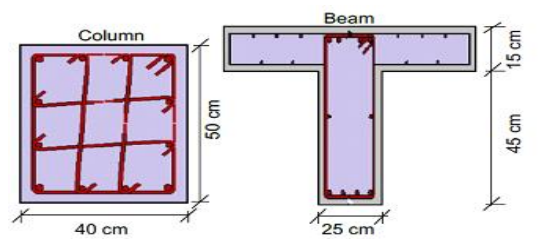

Figure 5. Beam and columns cross-sections

All these structural characteristics were instant in all structural models that used in this study. The variables were total number of stories and footprint area.

\subsection{Analysis Results}

Base shear force, elastic stiffness (K_elas) and effective stiffness (K_eff) were calculated separately for each number of stories and each structural model. The displacement values for damage estimation for structural models were obtained for three damage status according to Eurocode-8, Part 3 firstly. These are near collapse (NC), significant damage (SD) and damage limitation (DL). All these results were given in Table 2 .

Table 2. Analysis results for all structural models

\begin{tabular}{|c|c|c|c|c|c|c|c|}
\hline Model & $\begin{array}{c}\text { Period } \\
(\mathrm{s})\end{array}$ & $\begin{array}{c}\text { Base } \\
\text { Shear } \\
(\mathrm{kN})\end{array}$ & K_elas & K-eff & DL & SD & NC \\
\hline \multicolumn{8}{|c|}{ 5 story } \\
\hline 1 & 0,3494 & 6111,5 & 195509 & 90309 & 0.027 & 0.034 & 0.059 \\
\hline 2 & 0.3933 & 6321.05 & 180846 & 85362 & 0.030 & 0.038 & 0.066 \\
\hline 3 & 0.4368 & 6505.9 & 167281 & 80496 & 0.033 & 0.042 & 0.074 \\
\hline \multicolumn{8}{|c|}{ 6story } \\
\hline 1 & 0.4191 & 6274.1 & 168927 & 77966 & 0.031 & 0.040 & 0.070 \\
\hline 2 & 0.4712 & 6515.5 & 157325 & 73661 & 0.035 & 0.045 & 0.078 \\
\hline 3 & 0.5230 & 6722.9 & 151360 & 69585 & 0.039 & 0.050 & 0.087 \\
\hline \multicolumn{8}{|c|}{ 7story } \\
\hline 1 & 0.4898 & 6421.5 & 147297 & 68383 & 0.036 & 0.047 & 0.081 \\
\hline 2 & 0.5497 & 6687.2 & 144829 & 65088 & 0.040 & 0.052 & 0.090 \\
\hline 3 & 0.6097 & 6914.7 & 141399 & 60879 & 0.045 & 0.058 & 0.100 \\
\hline \multicolumn{8}{|c|}{ 8story } \\
\hline 1 & 0.5615 & 6528.4 & 141882 & 61010 & 0.041 & 0.053 & 0.091 \\
\hline 2 & 0.6290 & 6830.7 & 133670 & 58052 & 0.046 & 0.059 & 0.102 \\
\hline 3 & 0.6971 & 7075.9 & 124809 & 54417 & 0.051 & 0.065 & 0.113 \\
\hline
\end{tabular}

The first value refers to displacement at the moment of yield $\left(d_{y}\right)$, the second value refers to the intermediate ( $\left.d_{\text {int }}\right)$ displacement and the third value refers to the target displacement $\left(\mathrm{d}_{\mathrm{t}}\right)$. All these displacement values were obtained from pushover curves and shown in Table 3.
Table 3. Comparison of the displacements

\begin{tabular}{|l|l|l|l|}
\hline Model & $d_{y}(\mathrm{~m})$ & $\mathrm{d}_{\text {int }}(\mathrm{m})$ & $\mathrm{d}_{\mathrm{t}}(\mathrm{m})$ \\
\hline \multicolumn{4}{|c|}{ 5 story } \\
\hline 1 & 0.0677 & 0.1260 & 0.300 \\
\hline 2 & 0.0740 & 0.1320 & 0.300 \\
\hline 3 & 0.0810 & 0.1440 & 0.300 \\
\hline \multicolumn{4}{|c|}{$\mathbf{6}$ story } \\
\hline 1 & 0.0805 & 0.1380 & 0.300 \\
\hline 2 & 0.0885 & 0.1500 & 0.300 \\
\hline 3 & 0.0966 & 0.1620 & 0.300 \\
\hline \multicolumn{5}{|c|}{$\mathbf{7}$ story } \\
\hline 1 & 0.0939 & 0.1560 & 0.300 \\
\hline 2 & 0.1027 & 0.1680 & 0.300 \\
\hline 3 & 0.1136 & 0.1860 & 0.300 \\
\hline \multicolumn{4}{|c|}{$\mathbf{8}$ story } \\
\hline 1 & 0.1070 & 0.1800 & 0.300 \\
\hline 2 & 0.1177 & 0.1920 & 0.300 \\
\hline 3 & 0.1300 & 0.2040 & 0.300 \\
\hline
\end{tabular}

The comparison of pushover curves that obtained from structural analysis for different structural footprint area for 5-story was given in Figure 6; 6-story was given in Figure 7;7-story was given in Figure 8 and 8 -story was given in Figure 9.

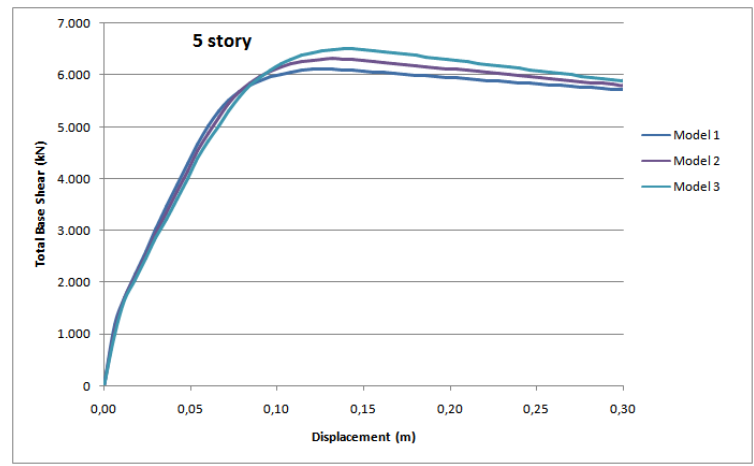

Figure 6. The comparison of pushover curves for 5-story for different structural models

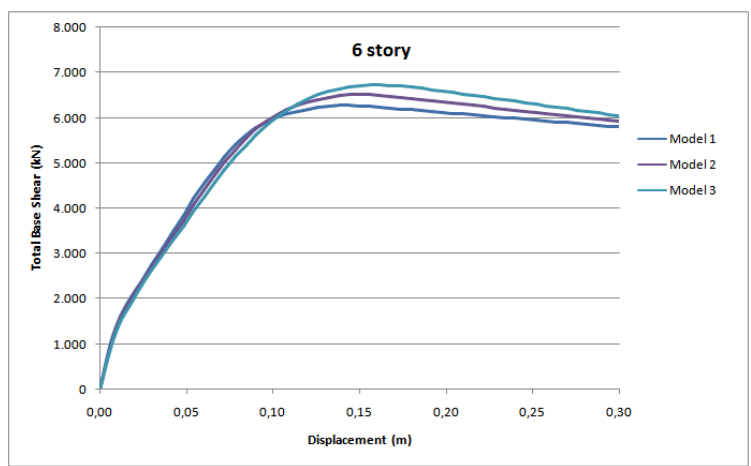

Figure 7. The comparison of pushover curves for 6-story for different structural models 


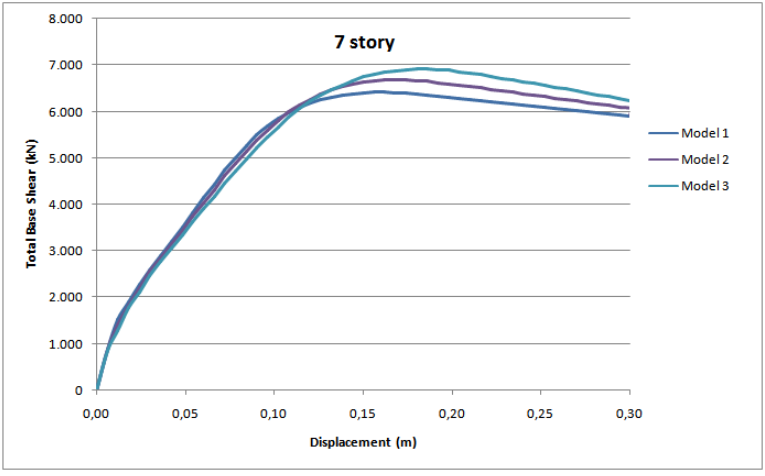

Figure 8. The comparison of pushover curves for 7-story for different structural models

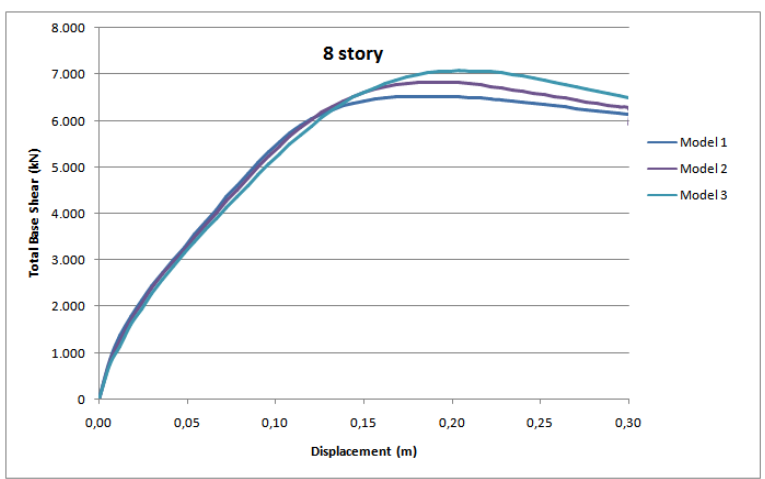

Figure 9. The comparison of pushover curves for 8-story for different structural models

The comparison of pushover curves for different number of stories for Model 1 was given in Figure 10. The pushover curves for other structural models were obtained same. So only for Model 1 was given.

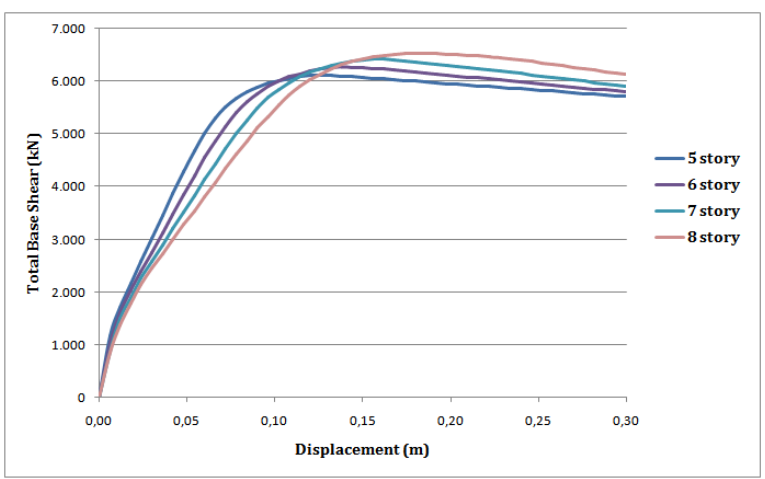

Figure 10. The comparison of pushover curves for different story number for Model 1

The period and displacement values for damage estimation for structural models were obtained for three damage status according to Turkish Seismic Design Code -2018 (TSDC2018). These values were given in Table 4.
Table 4. The results according to TSDC-2018

\begin{tabular}{|c|c|c|c|c|c|}
\hline Model & $\begin{array}{c}\text { Period } \\
(\mathrm{s})\end{array}$ & $\begin{array}{c}\text { Continuous } \\
\text { Use (KK) }\end{array}$ & $\begin{array}{c}\text { Immediate } \\
\text { Occupancy } \\
(\mathrm{HK})\end{array}$ & $\begin{array}{c}\text { Life } \\
\text { Safety } \\
(\mathrm{CG})\end{array}$ & $\begin{array}{c}\text { Collapse } \\
\text { Prevantation } \\
(\mathrm{BP})\end{array}$ \\
\hline \multicolumn{7}{|c|}{ 5 story } \\
\hline 1 & 0.593294 & 0.02078 & 0.02909602 & 0.039487 & 0.04780 \\
\hline 2 & 0.658507 & 0.02315 & 0.03241832 & 0.043996 & 0.053258 \\
\hline 3 & 0.72239 & 0.02550 & 0.03570315 & 0.048454 & 0.058655 \\
\hline \multicolumn{7}{|c|}{$\mathbf{6}$ story } \\
\hline 1 & 0.71297 & 0.02507 & 0.03510615 & 0.047644 & 0.057674 \\
\hline 2 & 0.790192 & 0.02789 & 0.03905054 & 0.052997 & 0.064154 \\
\hline 3 & 0.866262 & 0.03069 & 0.04297596 & 0.058324 & 0.070603 \\
\hline \multicolumn{7}{|c|}{$\mathbf{7 ~ s t o r y}$} \\
\hline 1 & 0.834032 & 0.02942 & 0.04119793 & 0.055911 & 0.067682 \\
\hline 2 & 0.922894 & 0.03267 & 0.04574184 & 0.062078 & 0.075147 \\
\hline 3 & 1.010913 & 0.03592 & 0.05029363 & 0.068255 & 0.082625 \\
\hline \multicolumn{7}{|c|}{$\mathbf{8}$ story } \\
\hline 1 & 0.956597 & 0.03384 & 0.04737902 & 0.06430 & 0.077836 \\
\hline 2 & 1.056697 & 0.03749 & 0.05249742 & 0.071246 & 0.086245 \\
\hline 3 & 1.156408 & 0.04118 & 0.05765996 & 0.07825 & 0.094727 \\
\hline
\end{tabular}

\section{Results}

The importance of structural dimensions and number of stories were mentioned within the scope of the study. Structural dimensions and total number of stories in the building can take different values due to different reasons. Within the scope of this study, two different structural analyses were carried out considering the change in the number of stories and structural dimensions. It is determined that there is a complete agreement between all the results obtained.

As the structural footprint area increased, the structure became less rigid. Consequently, the period value decreased as the footprint area decreased and seismic capacity decreased in RC structures. As the number of story decreases, the period value increases, the stiffness value decrease and seismic capacity increase. The increase in the footprint area and number of story caused the structure to be less rigid.

As a result of the analyses, the greatest percentages of change were observed at the target displacements predicted for the structure. Target displacement values for the settlement at the moment of yield (dy), near collapse (NC), significant damage (SD) and damage limitation (DL) increased depending on the footprints and number of stories. The increase in target displacements in terms of performance criteria reveals the direct relationship between the damage occurring in the earthquake and the number of stories in RC structures.

The period and displacements for damage estimation were calculated for Eurocode 8, Part 3 and TSDC-2018, respectively in this study. A complete agreement has been achieved between these values obtained for Eurocode 8 and TSDC- 2018, separately according to changing structural footprint area and number of stories. However, the period values obtained for TSDC-2018 were higher than Eurocode- 
8. Period values increase because of TSDC -2018 allows more translation of structures.

According to TSDC - 2018, both elastic and effective stiffness values decreased as the number of floors increased. As a result, period values also increased. Period values increased as the building structural footprint area increased. Target displacement values calculated for performance levels depending on TSDC-2018 increased as the number of stories increased. These target displacements increased as the structural footprint area increased. As the number of stories and structural footprint area increases, expected performance levels are a result of the need to increase.

The importance of structural dimensions and number of floors were mentioned within the scope of the study. Unnecessary increase in dimensions and number of floors adversely affects structural analysis.

\section{References}

Ademovic, N., Hrasnica, M., Oliveira, D.V., 2013. Pushover analysis and failure pattern of a typical masonry residential building in Bosnia and Herzegovina. Engineering Structures, 50, 13-29.

Antoniou, S., Pinho, R., 2003. Seismostruct - Seismic Analysis program by Seismosoft. Technical manual and user manual.

Chopra, A.K., Goel, R.K., 2002. A modal pushover analysis procedure for estimating seismic demands for buildings. Earthquake Engineering \& Structural Dynamics, 31(3), 561-582.

Estêvão, J. M., Oliveira, C. S., 2015. A new analysis method for structural failure evaluation. Engineering Failure Analysis, 56, 573-584.

Hadzima-Nyarko, M., KalmanSipos, T., 2017. Insights from existing earthquake loss assessment research in Croatia. Earthquakes and Structures, 13(4), 365-375.

İlerisoy, Z.Y., Tuna, M.E. 2018. Effects of plane dimensions and number of storeys on the cost of rectangular-plane buildings constructed with tunnel Form Megaron, 13(4), 559-568.

Ișlk, E., 2016. Consistency of the rapid assessment method for reinforced concrete buildings. Earthquakes and Structures, 11(5), 873-885.

Işık, E., Karaşin, İB., 2020, The mutual interaction between the structural footprint and number of floors in steel structures . Unpublished article.

Işık, E., Kutanis M., 2015. Performance based assessment for existing residential buildings in Lake Van basin and seismicity of the region. Earthquakes and Structures, 9(4), 893-910.

Ișık, E., Özdemir, M., 2017. Performance based assessment of steel frame structures by different material models. International Journal of Steel Structures, 17(3), 1021-1031.

Işık, E., Özdemir, M., Karaşin, İ. B., 2018. Performance analysis of steel structures with A3 irregularities. International Journal of Steel Structures, 18(3), 1083-1094.

Ișık, E., Ișlk, M. F., \& Bülbül, M. A. 2017. Web based evaluation of earthquake damages for reinforced concrete buildings. Earthquakes and Structures, 13(4), 387-396.
Kutanis, M., Boru, E. O., Işık, E., 2017. Alternative instrumentation schemes for the structural identification of the reinforced concrete field test structure by ambient vibration measurements. KSCE Journal of Civil Engineering, 21(5), 17931801.

Özdemir, M., Işık, E., Ülker, M., 2016. Performance evaluation of reinforced concrete buildings with different story numbers. BEU Journal of Science, 5(2), 183-190.

Pinto, P. E. (2005). The Eurocode 8-Part 3: the new European Code for the seismic assessment of existing structures.

Saidu, İ.,Alumbugu, P.O., Abdulazeez, A., Ola-Awo, W.A., 2015. Assessment of the effect of plan shapes on cost of institutional buildings in Nigeria, International Refereed Journal of Engineering and Science (IRJES), 4(3), 39-50.

SeismoStruct, 2016. A computer program for static and dynamic nonlinear analysis of framed structures. Seismosoft.

Şengezer, B.S.1999. The damage distribution during March 13, 1992 Erzincan earthquake. YT U. Press Release Center, 13.

Sucuoğlu, H., 2007. A screening procedure for seismic risk assessment in urban building stocks. Sixth National Conference on Earthquake Engineering, Istanbul, Turkey.

Turkey Seismic Design Code (TSDC-2018), Ankara, Turkey.

Yakut, A., 2004. Preliminary seismic performance assessment procedure for existing RC buildings. Engineering Structures, 26(10), 1447-1461. 